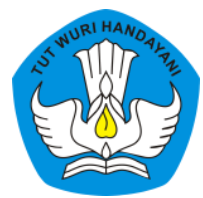

Page: $31-46$

\title{
PENGEMBANGAN MEDIA PEMBELAJARAN PERMAINAN EDUKATIF CARI KATA BERBASIS ANDROID UNTUK MENSTIMULASI PEMBELAJARAN HOTS
}

\author{
Gustina \\ Sekolah Dasar Negeri 02 Payakumbuh, Sumatera Barat, Indonesia \\ Contributor Email: ghustina625@gmail.com
}

Received: Jan 16, 2021

Accepted: Mar 9, 2021

Published: Mar 30, 2021

Article Url: $\underline{\text { https://ojsdikdas.kemdikbud.go.id/index.php/didaktika/article/view/269 }}$

\begin{abstract}
This research is motivated by the use of learning media for educational games based on android which are still rarely found, even though it is known that $21^{\text {st-century }}$ learning models of learning and learning media are unlimited, and are carried out with the help of information and communication technology. Students are required to think critically, creatively in solving problems in new situations (HOTS). This study aims to produce learning media for android-based educational word search games to stimulate HOTS learning in social studies subjects. This type of research is development research with a 4-D model. This research was conducted at Public Elementary School 54 Payakumbuh with the subject of grade VI students. The results obtained from this study are an educational game looking for words based on android, which can improve student learning outcomes. The results of the validity test of learning media by media experts, material experts, and linguists are very good results. The practicality test of the assessment media was carried out by 25 students, and the assessment by the parents of the students was very good. The test of the effectiveness of learning media shows that student learning outcomes have increased. Based on these results, it was concluded that the learning media for word search educational games were developed and could stimulate HOTS learning.
\end{abstract}

Keywords: Word Search, Learning Media, Educational Games, Android, HOTS 


\begin{abstract}
Abstrak
Penelitian ini dilatarbelakangi oleh penggunaan media pembelajaran permainan edukatif berbasis android masih jarang dijumpai, padahal diketahui pembelajaran abad ke-21 model pembelajaran dan media pembelajaran tidak terbatas, dan dilakukan dengan bantuan teknologi informasi dan komunikasi. Siswa dituntut untuk berpikir kritis dan kreatif dalam menyelesaikan masalah pada situasi baru (HOTS). Penelitian ini bertujuan untuk menghasilkan media pembelajaran permainan edukatif Cari Kata berbasis android menstimulasi pembelajaran HOTS pada mata pelajaran IPS. Jenis Penelitian adalah penelitian pengembangan dengan model 4-D. Penelitian ini dilakukan di Sekolah Dasar Negeri 54 Payakumbuh dengan subjek siswa kelas VI. Hasil yang diperoleh dari penelitian ini adalah permainan edukatif cari kata berbasis android, dapat meningkatkan hasil belajar peserta didik. Hasil uji validitas media pembelajaran oleh ahli media, ahli materi, dan ahli bahasa diperoleh hasil sangat baik. Uji praktikalitas media penilaian oleh 25 siswa, dan penilaian oleh orang tua siswa diperoleh hasil sangat baik. Uji efektivitas media pembelajaran menunjukkan hasil belajar siswa mengalami peningkatan. Berdasarkan hasil tersebut, disimpulkan media pembelajaran permainan edukatif cari kata yang dikembangkan dapat menstimulasi pembelajaran HOTS.
\end{abstract}

Kata Kunci: Cari Kata, Media Pembelajaran, Permainan Edukatif, android, HOTS

\title{
A. Pendahuluan
}

Ditemukan dalam kurun 20 tahun terakhir ini terjadi pergeseran pembangunan pendidikan ke arah Information and Communication Technology (ICT), yang lebih dikenal dengan teknologi informasi dan komunikasi (TIK) sebagai salah satu strategi manajemen pendidikan abad ke- 21 yang meliputi tata kelola kelembagaan dan sumber daya manusia (Sasmoko, 2017). Abad ini memerlukan perubahan pendidikan secara utuh sehingga terbangun guru yang memajukan pengetahuan peserta didik untuk membimbing agar mereka didik memiliki keterampilan dan kemampuan di bidang teknologi, media dan informasi, serta inovasi keterbaruan. Saat ini pembelajaran abad ke-21 memiliki model pembelajaran yang sangat banyak, tidak terbatas ,dan dilakukan dengan bantuan teknologi informasi dan komunikasi. Pendidikan dan pengajaran di Indonesia dewasa ini menunjukkan perkembangan yang cukup baik apalagi ditambah dengan perkembangan kemajuan sistem teknologi 
informatika (TI) saat ini, dunia pendidikan selalu bergerak terus ke depan secara dinamis.

Selain menggunakan metode pembelajaran untuk meningkatkan kualitas pendidikan, upaya lain yang dilakukan adalah dengan penggunaan media. Menurut Susilana (2016), “Media merupakan bagian dari proses komunikasi, karena pada dasarnya pembelajaran merupakan proses komunikasi" 2016). Media pembelajaran yang dirancang secara baik akan sangat membantu peserta didik dalam mencerna dan memahami materi pelajaran. Menurut Muhson berpendapat, "Media pembelajaran dapat merupakan wahana penyalur pesan dan informasi belajar" (Muhson, 2013). Media pembelajaran berfungsi sebagai perantara antara guru dan siswa dalam proses pembelajaran. Dalam hal ini, peneliti membatasi pengertian media dalam pendidikan saja, yakni media yang digunakan sebagai alat dalam kegiatan belajar mengajar.

Media pembelajaran akan semakin berkembang dengan pesat. Penggunaan media perlu diadakan penemuan baru yang lebih baik. Media yang digunakan harus menarik dan sesuai dengan karakteristik peserta didik sehingga dapat memotivasi untuk belajar (Kaylene \& Rosone, 2016). Aspek kemenarikan ini dapat dilakukan dengan menerapkan teknik belajar sambil bermain. Karena salah satu karakteristik anak sekolah dasar adalah bermain, dunia yang penuh spontanitas dan menyenangkan. Seorang anak akan belajar dengan semangat apabila pembelajaran disampaikan dengan cara yang menyenangkan (Handayani, M. E., 2018).

Seperti halnya dalam dua kehidupan, alangkah lebih menarik dan menyenangkan jika dijalani dengan penuh variasi, begitu juga variasi dalam proses pembelajaran juga perlu dikembangkan. Variasi belajar mengajar merupakan suatu perubahan dalam proses kegiatan yang bertujuan untuk meningkatkan motivasi pembelajar. Sesuai yang diungkapkan oleh Amini dan kawan-kawan bahwa salah satu upaya paling praktis dan realistis di Indonesia meningkatkan kualitas proses pembelajaran dan hasil belajar peserta didik adalah peningkatan dan penyempurnaan sistem pembelajaran (Amini, 2018). 
Berkembangnya variasi pembelajaran begitu cepat menciptakan sebuah pembaharuan media pembelajaran yang sangat bervariasi. Salah satu media pembelajaran yang saat ini banyak dikembangkan ialah penggunaan media pembelajaran permainan edukatif berbasis android. Menurut Maulana fenomena penggunaan teknologi yang kurang bermanfaat terjadi saat ini sebagai contoh seorang anak menggunakan smartphone atau androidnya hanya sebagai media bermain dan kurang mendidik (Maulana, 2018). Permasalahan tersebut dapat diperbaiki salah satunya dengan dibuatnya sebuah aplikasi permainan edukatif yang mendidik.

Permainan edukatif adalah permainan yang berguna untuk meningkatkan daya pikir dan juga termasuk meningkatkan konsentrasi dan memecahkan masalah (Handriyantini, 2009). Peserta didik dikatakan mampu menyelesaikan masalah jika mereka bisa menggunakan pengetahuannya dengan cara berpikir kritis ke dalam situasi baru seperti dalam situasi melakukan permainan. Ini sesuai dengan pembelajaran HOTS yang sering didengungkan oleh para pendidik. Tujuan pembelajaran dengan high order thinking skills (HOTS) adalah meningkatkan kemampuan memecahkan masalah, berpikir kritis, kreatif, mengeluarkan pendapat dalam menerima berbagai informasi menggunakan pengetahuan yang mereka miliki (Saputra, 2017).

Kenyataannya, sebagian besar anak-anak dan remaja menyukai game sebagai sarana hiburan dari rutinitas belajar di sekolah setiap harinya. Pemaanfaatan teknologi informasi dalam media pembelajaran tersebut salah satunya adalah pengembangan media pembelajaran berbasis permainan edukatif. Multimedia memberikan kesempatan kepada siswa untuk belajar tidak hanya dari satu sumber seperti guru, tetapi memberikan kesempatan kepada subjek belajar untuk mengembangkan kemampuan kognitif dengan lebih baik, kreatif, dan inovatif. Apalagi di sekolah-sekolah sekarang sudah tersedia koneksi internet berkecepatan tinggi ( $\mathrm{Wi}-\mathrm{Fi}$ ) yang bisa digunakan oleh seluruh 
warga sekolah termasuk peserta didik. Peserta didik bisa menggunakan akses internet untuk kepentingan pembelajaran yang sering dilakukan pada saat jam pelajaran pengembangan diri di sekolah.

Dilihat keadaan sebenarnya kemajuan teknologi belum sejalan penerapannya dalam bidang pendidikan khususnya pada mata pelajaran Ilmu Pengetahuan Sosial di Sekolah Dasar. Penggunaan media pembelajaran berbasis permainan edukatif di android dalam pembelajaran IPS di SD masih jarang dijumpai. Berdasarkan observasi dan wawancara yang peneliti laksanakan di Sekolah Dasar Negeri 54 Payakumbuh, Kecamatan Payakumbuh Barat, Kota Payakumbuh, ditemukan permasalahan terkait media pembelajaran yang digunakan pada materi peristiwa alam yang terjadi di Indonesia dan negara tetangga, yaitu guru menggunakan media pembelajaran yang kurang sesuai, berupa gambar peristiwa alam hanya memakai karton untuk membantu siswa memahami materi tentang peristiwa alam yang terjadi di Indonesia dan negara tetangga. Beberapa permasalahan yang teridentifikasi adalah (1) guru kurang mengikuti perkembangan IPTEK dalam pengembangan media pembelajaran berbasis IT; (2) kurangnya sarana multimedia interaktif dalam pembelajaran berupa bentuk permainan yang bisa menstimulasi pembelajaran HOTS; serta (3) siswa terlihat kurang aktif dalam pembelajaran, dan siswa kurang mampu mengungkapkan ide atau gagasan yang dimilikinya serta menyatukan ide dalam kegiatan belajar.

Salah satu yang dapat dikembangkan untuk mengatasi permasalahan tersebut dengan memantapkan proses pembelajaran melalui penggunaan media permainan edukatif berbasis android. Dengan media ini siswa langsung melakukan permainan edukatif tersebut untuk memantapkan materi pembelajaran dan guru dapat mengaktifkan siswa dalam proses pembelajaran dengan benda konkret. Sudah banyak guru yang memanfaatkan media komputer dalam pembelajaran seperti Software Powerpoint dan lainnya untuk menjelaskan materi pelajaran. Walaupun software tersebut sangat bagus, tetapi presentasi pelajaran 
menggunakan software Powerpoint belum mampu sepenuhnya melibatkan siswa secara aktif. Tentu ini bertentangan dengan metode pembelajaran pembelajaran aktif, inovatif, kreatif, efektif, dan menyenangkan/ PAIKEM (Adnan, 2018)

Pengembangan media pembelajaran permainan edukatif Cari Kata berbasis android untuk menstimulasi pembelajaran HOTS dimanfaatkan sebagai alat pendukung pembelajaran Ilmu Pengetahuan Sosial sehingga proses pembelajaran akan lebih menarik minat siswa dan memberikan kemudahan untuk memahami materi karena penyajian yang menarik. Maka dari itu rumusan masalah penelitian ini adalah bagaimana validitas, praktikalitas, dan efektivitas media pembelajaran permainan edukatif cari kata berbasis android untuk menstimulasi pembelajaran HOTS. Tujuan penelitian ini adalah menghasilkan media permainan berbasis android yang valid, praktis, efektif, menarik, menyenangkan dan dapat menstimulasi pembelajaran HOTS.

Penggunaan media pembelajaran bukan merupakan sebagai fungsi tambahan saja, tetapi memiliki fungsi dan manfaat tersendiri untuk membantu menciptakan suasana pembelajaran yang lebih efektif. Menurut Rahm, media teknologi dan pengajaran dapat membantu guru menciptakan kegiatan yang aktif, menarik, dan bermakna belajar (Rahmi, U., \& Helsa, 2018). Permainan edukatif adalah permainan yang dirancang atau dibuat untuk merangsang daya pikir termasuk meningkatkan konsentrasi dan memecahkan masalah (Handriyantini, 2009). Ini sesuai dengan hakikat pembelajaran HOTS yaitu menuntut keterampilan berpikir tingkat tinggi dan berpikir kritis. Berpikir tingkat tinggi adalah jenis pemikiran yang mencoba mengeksplorasi pertanyaan-pertanyaan mengenai pengetahuan yang ada terkait isu-isu yang tidak didefinisikan dan tidak memiliki jawaban pasti (Haig, 2014).

Susun kata adalah salah satu game atau permainan buatan pengembang Indonesia yang dapat melatih konsentrasi dan mempertajam kemampuan otak peserta didik (Azmil, 2013). Permainan Cari kata ini 
termasuk multimedia pembelajaran. Multimedia pembelajaran merupakan bagian dari pembelajaran berbasis elektronik (Rusli, M, Dadang H, 2019). Pembelajaran berbasis elektronik contohnya bisa dilakukan melalui android. Agustina (2015) menambahkan bahwa "Android adalah platform open source yang dirancang untuk perangkat mobile android menyediakan semua tools dan framework untuk mengembangkan aplikasi mobile dengan cepat dan mudah".

\section{B. Metode}

Metode penelitian pengembangan yang digunakan merujuk pada model pengembangan 4D. Menurut Mulyadi (2017) tahap 4D oleh meliputi, "tahap pendefinisian (define), tahap perancangan (design), tahap pengembangan (development), dan tahap penyebaran (dessiminate) (Mulyadi, 2017). Subjek uji coba lapangan dilakukan langsung pada responden yang berasal dari guru dan siswa kelas VI Sekolah Dasar Negeri 54 Payakumbuh. Media permainan edukatif Cari Kata ini untuk menstimulasi keefektifan dan kepraktisan pembelajaran HOTS.

Bagian awal penelitian ini adalah pengumpulan data dengan melakukan observasi dalam rangka pengukuran atau analisis kebutuhan serta permasalahan-permasalahan yang terjadi dalam pembelajaran (Titis Prilanto, n.d.). Teknik pengumpulan data dalam penelitian ini adalah menggunakan tes evaluasi belajar dan lembar pengamatan (efektivitas), angket (praktikalitas), dan dokumentasi. Jenis angket yang digunakan adalah angket tertutup, yang berarti responden harus memilih jawaban yang sudah tersedia, skala yang digunakan adalah skala Likert (skala ukur 5) dan skala guttman (ya/tidak).

Instrumen Pengumpulan data adalah "alat bantu yang dipilih dan digunakan oleh peneliti dalam kegiatannya mengumpulkan data agar kegiatan tersebut menjadi sistematis dan dipermudah olehnya," (Burhanuddin, 2013). Alat pengumpul data yang digunakan dalam penelitian ini adalah lembaran angket atau kuesioner, soal tes, dan 
dokumentasi. Format penilaian dalam penelitian ini menggunakan skala Likert. Arifin (2012) mengungkapkan bahwa "Skala Likert digunakan untuk mengukur sikap peserta didik yang mana peserta didik disuruh memilih pernyataan-pernyataan yang positif saja, tetapi memilih juga pernyataan yang negatif juga" .

Pada teknik analisis data, data yang diperoleh melalui kegiatan uji coba diklasifikasikan menjadi dua, yaitu data kualitatif dan data kuantitatif. Data kualitatif mengenai kualitas multimedia interaktif diperoleh dari masukan saran dan kritik guru mata pelajaran, ahli IT media, dan siswa sebagai subjek uji coba. Kemudian data dihimpun, dianalisis, dan disimpulkan untuk memperbaiki produk yang dikembangkan. Data kuantitatif didapat dari pengisian angket yang dilakukan oleh guru mata pelajaran, ahli media, dan siswa.

\section{Hasil dan Pembahasan}

Penelitian ini fokus pada pengembangan media pembelajaran permainan edukatif cari kata berbasis android untuk menstimulasi pembelajaran HOTS. Berikut disajikan data hasil dan pembahasan penelitian sesuai dengan tujuan dan prosedur pengembangan yang digunakan dalam penelitian ini.

Hasil penelitian pada tahap define, yaitu diketahui bahwa kurikulum yang digunakan masih kurikulum 2006 tidak semua peserta didik memiliki buku, metode belajar hanya berupa ceramah, kurang tersedianya multimedia interaktif, dan proses pembelajaran IPS lebih menekankan teacher centered. Hasil dari analisis kurikulum adalah rancangan produk yang dihasilkan ada kesesuaian dan kecocokan materi dengan permainan yang dimainkan dalam permainan edukatif. Hasil analisis materi dalam media pembelajaran yang peneliti kembangkan sudah sesuai dengan silabus dan karakteristik materi pembelajaran pada Kurikulum 2006 sesuai analisis kurikulum. Hasil analisi media, guru tertarik menggunakan media permainan edukatif berbasis android untuk 
menstimulasi pembelajaran HOTS. Analisis siswa berasal dari hasil observasi, wawancara, diskusi dan teori, ditemukan bahwa media pembelajaran yang akan dikembangkan dapat digunakan, menarik, dan dapat menstimulasi pembelajaran HOTS di kelas.

Tahap design dimulai dengan merancang media permainan edukatif cari kata berbasis android yang dikembangkan dan diujicobakan kepada siswa kelas VI Sekolah Dasar Negeri 54 Payakumbuh kecamatan Payakumbuh Barat kota Payakumbuh. Perancangannya dimulai dengan menyusun materi pembelajaran dan RPP sesuai materi, mengirim surat izin kepada orang tua siswa untuk membawa android ke sekolah, menyusun soal tes evaluasi dan kunci jawaban, memilih media, yaitu media permainan edukatif cari kata berbasis android, memilih format dengan cara membuat design beserta komponen media pembelajaran yang akan dibuat yang dilakukan bersama ahli IT, dan membuat rancangan media bersama ahli IT.

Pada tahap development (pengembangan) dilakukan uji validitas, praktikalitas, dan efektivitas. Aspek validitas yang dinilai yaitu aspek media, materi, dan bahasa. Aspek media diperoleh jumlah skor awal 40, skor rata-rata 2.67 dan persentase skor 63 dengan kategori baik (B). Aspek materi yang dinilai validator diperoleh jumlah skor 49 , skor rata-rata 3.06 dan persentase skor 77 pada kategori baik (B), dan aspek bahasa diperoleh jumlah skor 31, rata-rata 2.82 dan persentase skor 70 pada kategori baik (B). Data uji praktikalitas media permainan edukatif berbasis android berupa data primer yaitu data yang langsung diperoleh dari guru, siswa, dan orang tua siswa menggunakan instrumen penilaian berupa angket. Dari data tersebut diketahui bahwa guru, siswa, dan orangtua sepakat bahwa permainan edukatif Cari Kata ini praktis digunakan.

Data hasil uji efektivitas media pembelajaran permainan edukatif Cari Kata berbasis android diperoleh dari hasil belajar siswa. Hasil belajar dinilai pada ketiga ranah pembelajaran, yaitu kognitif (pengetahuan), 
afektif (sikap), dan psikomotor (keterampilan). Hasil belajar siswa ranah kognitif pada tahap uji coba berada pada kategori sangat baik (SB). Siswa memperoleh jumlah skor keseluruhan 2080 dengan nilai rata-rata 83.20 (SB). Persentase ketuntasan dari 25 siswa, yaitu 84\% (B) berjumlah 21 siswa yang tuntas, sedangkan siswa yang tidak tuntas, yaitu 16\% sebanyak 4 siswa. Hasil penilaian ranah afektif pada uji coba di atas diperoleh jumlah skor dari tiga aspek (keefektifan, tanggung jawab, dan menghargai) yang dinilai, yaitu 230 dengan rata-rata skor 3, 07 (B). Hasil penilaian ranah psikomotor pada uji coba diperoleh jumlah skor pada 2 aspek (keterampilan menggunakan media dan diskusi) yang dinilai, yaitu 161 dengan rata-rata 3.22 (B).

Tahap penyebaran (diseminate) dilaksanakan di kelas VI SDN 28 Payakumbuh kecamatan Payakumbuh Barat. Pada tahap ini Guru melaksanakan pembelajaran menggunakan media permainan edukatif cari kata berbasis android. Data yang diperoleh, yaitu data uji efektivitas dari hasil belajar siswa. Berikut ini beberapa foto aktivitas siswa menggunakan media pembelajaran permainan edukatif Cari Kata berbasis android yang nantinya akan menstimulasi pembelajaran HOTS.

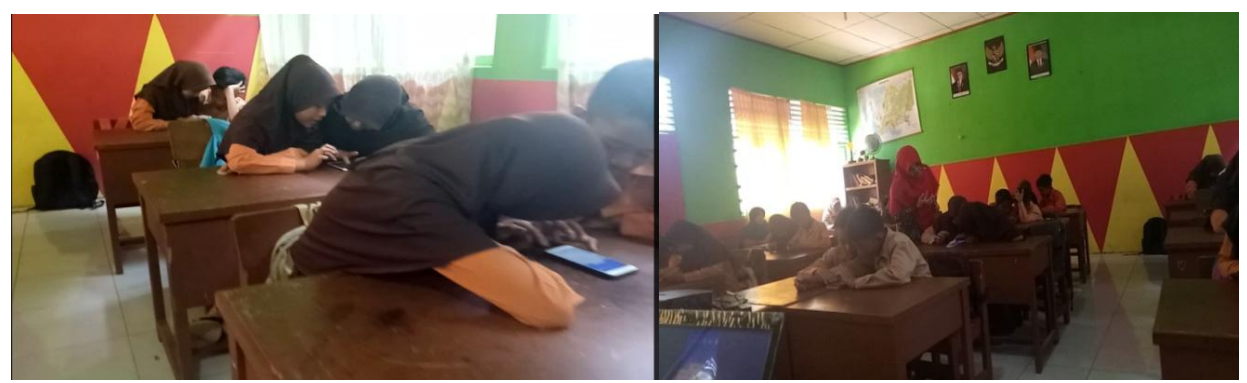

Gambar 1. Uji coba Produk pada Siswa Kelas VI

Sekolah Dasar Negeri 54 Payakumbuh

Berikut salah satu tampilan media permainan edukatif yang divalidasi oleh validator. 

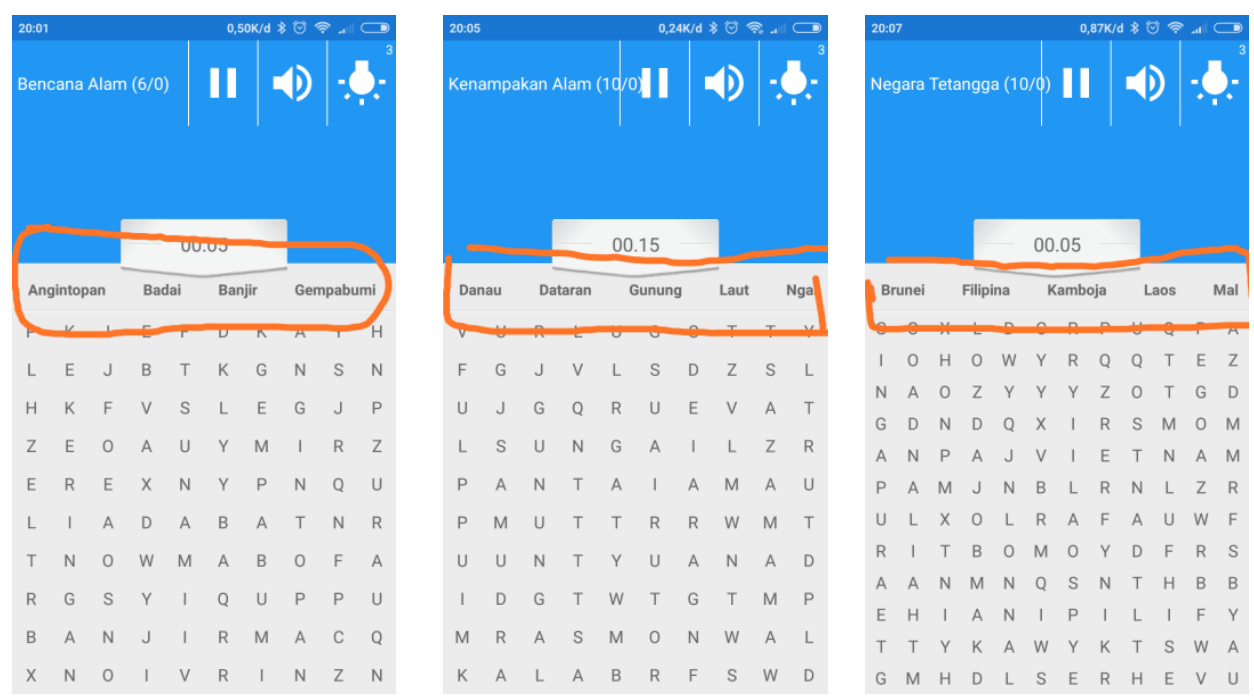

Gambar 2. Penambahan Kategori Permainan Edukatif

Hasil penilaian produk media permainan edukatif cari kata berbasis android untuk menstimulasi pembelajaran HOTS sudah sangat baik. Dapat dilihat hasil uji validitas media validitas oleh ahli media validitas pertama diperoleh persentase kategori baik. Validitas media oleh ahli media diperoleh data dengan rata-rata 3,73 dengan persentase $93 \%$ kategori sangat baik. Validitas pertama yang dilakukan oleh ahli materi diperoleh rata-rata 3,06 dengan persentase $77 \%$ kategori baik, sedangkan dari validasi ahli materi kedua diperoleh rata-rata 3,81 persentase $95 \%$ kategori sangat baik. Berdasarkan validasi dari ahli bahasa diperoleh data validitas pertama dengan rata-rata 2,82 persentase $70 \%$ kategori baik, serta validitas ahli bahasa kedua diperoleh rata-rata 3,55 persentase $89 \%$ kategori sangat baik.

Dari penilaian uji praktikalitas media oleh guru diperoleh persentase skor $82,69 \%$ (SB). Dari penilaian oleh siswa memperoleh persentase skor 92,83\% (SB), dan penilaian oleh orang tua siswa memperoleh persentase skor 71,21 \% (B). Hasil uji efektivitas media dilihat dari hasil belajar siswa, yaitu aspek kognitif, afektif dan psikomotor pada tahap uji coba produk secara keseluruhan berada pada 
kategori baik dan sangat baik. Aspek kognitif memperoleh nilai rata-rata 83.20 (SB) dengan persentase ketuntasan 84\% dari 25 siswa., aspek afektif memperoleh skor rata-rata 3.06 (B) dan aspek psikomotor memperoleh skor rata-rata $3.22(\mathrm{~B})$.

Tabel 1 Rekap Hasil Validasi dengan Validator

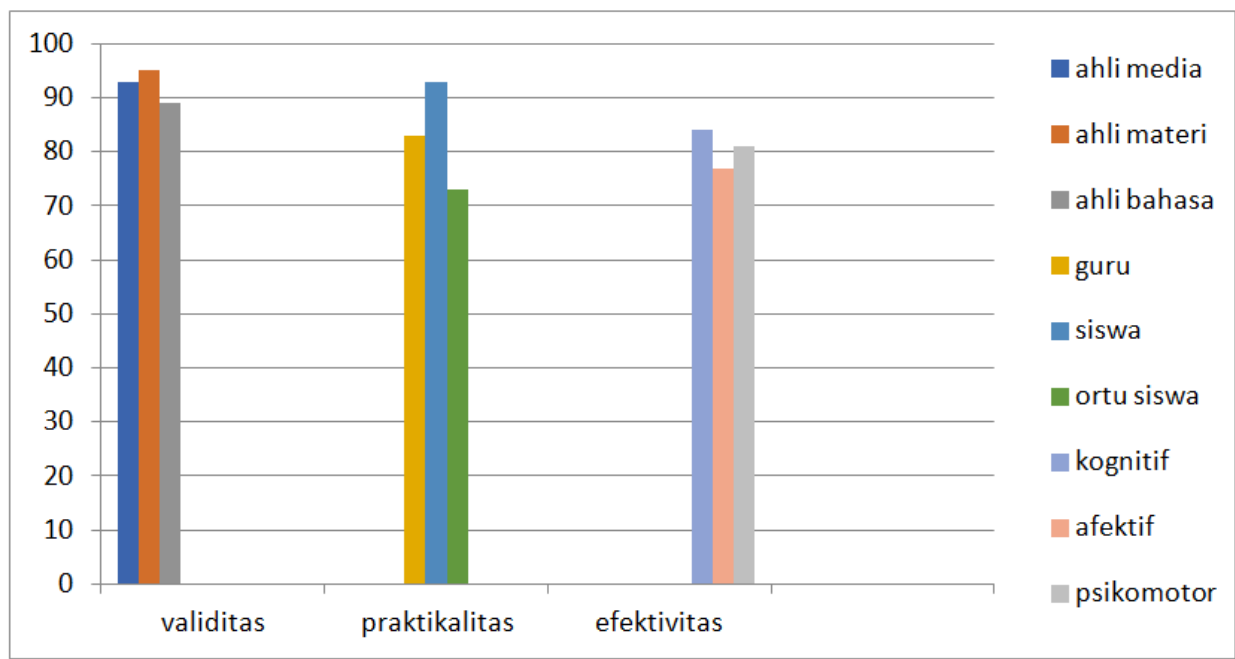

Beberapa hasil penelitian sebelumnya juga mengemukakan dampak positif penggunaan media android yang peneliti lakukan. Pemanfaatan media pembelajaran android di lingkungan Sekolah Dasar dirasa sangat perlu mengingat beberapa pertimbangan baik positif maupun negatif, serta android juga diangggap "teman" saat ini bagi masyarakat khususnya anak-anak di lingkungan sekolah dasar. Jika android dilibatkan dalam pembelajaran akan memotivasi siswa dalam memperoleh bahan ajar dan pembelajaran menjadi lebih menyenangkan" (Fitriansyah, 2016).

Wibawa (2017) mengungkapkan bahwa "perkembangan game semakin meningkat sehingga dapat dimainkan di berbagai macam media salah satunya Smartphone berbasis android". Mengingat dampak game yang beragam, dibuatlah game bertema edukasi yang dikhususkan untuk anak-anak agar mendapat hasil positif dari bermain game. Dampak game 
juga diungkapkan oleh Wahyudin bahwa menciptakan suasana belajar siswa dalam memanfaatkan android tidak terganggu tetapi tujuan guru atau orang tua dapat tercapai untuk membelajarkan siswa (Asep, 2018).

\section{Penutup}

Jika produk media pembelajaran permainan edukatif Cari Kata yang dihasilkan melalui data empiris membuktikan bahwa pengembangan media pembelajaran permainan edukatif Cari Kata berbasis android untuk pembelajaran Ilmu Pengetahuan Sosial sudah valid, praktis, dan efektif digunakan pada materi penampakan lingkungan alam sekitar di kelas VI Sekolah Dasar. Media pembelajaran permainan edukatif Cari Kata berbasis android yang telah dikembangkan dapat menjadi salah satu alternatif bagi guru dan siswa untuk membantu dan meningkatkan hasil belajar dalam pembelajaran Ilmu Pengetahuan Sosial. Selain itu, media pembelajaran permainan edukatif Cari Kata berbasis android dapat membuat pembelajaran IPS pada materi peristiwa alam (gejala alam) yang terjadi di Indonesia dan negara tetangga menjadi lebih bermakna, menarik, menyenangkan dan juga dapat dijadikan oleh siswa bahan pemantapan belajar secara mandiri tanpa bantuan Guru di rumah.

Dalam menggunakan media pembelajaran permainan edukatif Cari Kata berbasis android pada pembelajaran, terdapat beberapa hal yang harus dipersiapkan oleh guru dan siswa, yaitu: (1) Melengkapi prasyarat media pembelajaran, berupa sarana android yang dapat menjalankan media pembelajaran permainan edukatif Cari Kata; (2) Keterampilan dalam menggunakan media pembelajaran permainan edukatif Cari Kata berbasis android.

Selama proses pembelajaran berlangsung menggunakan media pembelajaran permainan edukatif Cari Kata berbasis android, siswa merasakan suasana yang berbeda dalam pembelajaran Ilmu Pengetahuan Sosial. Siswa menjadi aktif dan fokus pada media pembelajaran sesuai 
dengan bimbingan guru. Siswa bisa menemukan sendiri bahan materi peristiwa/gejala alam yang terjadi di Indonesia dan negara tetangga, karena terdapat tiga kategori materi pelajaran yang terdapat dalam media pembelajaran permainan edukatif Cari Kata. Hal ini akan menciptakan pembelajaran yang bermakna dan menyenangkan. Dengan demikian media pembelajaran permainan edukatif Cari Kata berbasis android dapat dijadikan sebagai salah satu media pembelajaran yang dapat digunakan dalam pembelajaran Ilmu Pengetahuan Sosial pada materi peristiwa alam (gejala alam) yang terjadi di Indonesia dan negara tetangga oleh guru dan siswa kelas VI SD di Kota Payakumbuh, Sumatera Barat.

\section{Ucapan Terima Kasih}

Ucapan terima kasih saya sampaikan kepada Direktorat Pembinaan Guru Pendidikan Dasar, Dirjen Guru dan Tenaga Kependidikan, Kementerian Pendidikan dan Kebudayaan RI, Dinas Pendidikan Kota Payakumbuh, Kepala Sekolah, dan rekan-rekan guru di Sekolah Dasar Negeri 54 Payakumbuh yang telah membantu dan memberikan kesempatan kepada saya sehingga dapat menyelesaikan penulisan artikel ilmiah ini.

\section{Daftar Referensi}

Adnan, M. (2018). Urgensi Penerapan Metode Paikem Bagi Guru Dalam Meningkatkan Mutu Pembelajaran Pendidikan Agama Islam. CENDEKIA: Jurnal Studi Keislaman, 3(1). https://doi.org/10.37348/cendekia.v3i1.42

Asep, W. (2018). Pengembangan Media Pembelajaran Persamaan Kuadrat Melalui Android untuk Meningkatkan Minat Belajar Siswa. Jurnal Didaktika Pendidikan Dasar, 2(1), 55-66.

Azmil, F. (2013). Pertajam Kemampuan Otak dengan game Susun Kata. https://m.merdeka.com/teknologi/

Burhanuddin, A. (2013). Pengumpulan Data dan Instrumen Penelitian. https://www.google.com/amp/s/afidburhanuddin.wordpress.co $\mathrm{m} /$ 
Fitriansyah, F. (2016). Pemanfaatan Media Pembelajaran (Gadget) Untuk Memotivasi Belajar Siswa SD. 2.

Haig, Y. (2014). Higher Order Thinking And Assesment. International Seminar on Current Issues in Primary Education: Prodi PGSD Universitas Muhammadiyah Makasar.

Handayani, M. E. dan, \& B. (2018). Pengaruh Metode Permainan Sirkuit Pintyar Terhadap Hasil Belajar Matematika Siswa Kelas IV SD. JPGSD, 06 Nomor 0, 49(23-6), 239-248.

Handriyantini, E. (2009). Permainan Edukatif (Educational Games) Berbasis Komputer Untuk Siswa Sekolah Dasar. E-Indonesia Invitiative 2009 (EII2009), 130.

Kaylene, P., \& Rosone, T. (2016). Multicultural Perspective On The Motivation of Students in Teaching Physical Education. Jurnal Ilmiah Peuradeun, 4(1), 115-126.

Maulana, Y. (2018). Jenius membuat Mobile Edukasi Android. CV. Mobidu Sinergi.

Muhson, A. (2013). Pengembangan Media Pembelajaran. Pendidikan Akuntansi Indonesia. https://doi.org/https://doi.org/10.2495/WM120321

Mulyadi. (2017). Kiat Sukses meraih Hibah Penelitian Pengembangan. CV Budi Utama.

R Amini, U. and Y. H. (2018). Integrated model in science for elementary school. IOP Conf. Series: Journal of Physics: Conf., Series 108, 1-5. https://doi.org/10.1088/1742-6596/1088/1/012057

Rahmi, U., \& Helsa, Y. (2018). Integrating technology and media into mathematics learning. Journal of Physics IOP Publishing. https://doi.org/10.1088/1742-6596/1088/1/012073

Rusli, M, Dadang H, N. N. S. (2019). Multimedia Pembelajaran yang Inovatif. In Penerbit Andi (Anggota IKAPI).

Saputra, H. (2017). Pengembangan Mutu Pendidikan Menuju Era Global: Penguatan Mutu Pembelajaran dengan Penerapan HOTS (High Order Thinking Skills). SMILE's Publishing. https://pgsd.binus.ac.id/2017/08/08/pendidikan-abad-21/

Sasmoko. (2017). Pendidikan Abad 21. Binus University Faculty of Humanities. https://pgsd.binus.ac.id/2017/08/08pendidikan-abad-21/ 
Susilana, R. \& C. (2016). Media Pembelajaran. CV Wacana Prima.

Titis Prilanto. (n.d.). Pengembangan Alat Permainan Edukatif Kokotar untuk Pembelajaran Tematik Integratif Kelas IV Di SDN Catur Tunggal 3 Sleman Yogyakarta. Universitas Negeri Yogyakarta. 